\title{
LEGITIMATION IMPLICATIONS IN THE PROCESS OF IMPLEMENTING AN ERP SYSTEM IN A HOLDING COMPANY
}

\author{
Viviane Theiss \\ Nayane Thais Krespi \\ Carlos Eduardo Facin Lavarda \\ Regional University of Blumenau, Blumenau, Santa Catarina, Brazil
}

\begin{abstract}
The objective of the study is to evaluate the legitimation of the process of implementing an ERP system in a holding company. The conceptual model is based on the New Institutional Sociology, with the evaluation of the legitimation of a new information system in the organization studied. The data collection procedures employed interviews, questionnaires, as well as the analysis of documents provided by the company. As the system is already part of the company's processes and the employees have already accepted the changes, it provides evidence of legitimation of the ERP system in the business.
\end{abstract}

Keywords: Enterprise Resources Planning; New Institutional Sociology; Legitimation; Deployment; Holding.

\section{INTRODUCTION}

The need to get the information across to owners and shareholders makes organizations seek alternatives to add promptness to their management processes, to enable better decision making and to boost competitive advantages. The trend is not to just surmised to the company itself, but to the whole supply chain and to accomplish the

Manuscript first received/Recebido em 28/02/2012 Manuscript accepted/Aprovado em: 01/03/2013

Address for correspondence / Endereço para correspondência

Viviane Theiss, Mestre em Ciências Contábeis - Universidade Regional de Blumenau Rua Antônio da Veiga, 140 - Sala D 203- Bairro Victor Konder.Caixa Postal 1507 - CEP 89012-900 - Blumenau - SC Fone: (47) 33210565 E-mail: vtheiss@al.furb.br

Nayane Thais Krespi, Mestre em Ciências Contábeis - Universidade Regional de Blumenau Rua Antônio da Veiga, 140 - Sala D 203- Bairro Victor Konder. Caixa Postal 1507 - CEP 89012-900 - Blumenau SC Fone: (47) 33210565 E-mail: nkrespi@al.furb.br

Carlos Eduardo Facin Lavarda, Doutor e Professor do Programa de Pós-Graduação em Ciências Contábeis - Universidade Regional de Blumenau Rua Antônio da Veiga, 140 - Sala D 203- Bairro Victor Konder. Caixa Postal 1507 - CEP 89012-900 - Blumenau - SC Fone: (47) 33210565 e-mail: clavarda@furb.br 
strategic and tactical plan for the chain, in addition to the company's operations (Padilha \& Marins, 2005).

The required changes reflect in the routines of the organization and the internal social relationships since the company will have to readjust and educate its players for new habits and routines to be accepted. The institutional approach emphasizes that, through legitimation, the actions of an entity become desirable, proper or appropriate within something socially accepted, which is constituted by a system of norms, values and beliefs (Deephouse \& Suchman, 2008). Thus, management control systems can be seen as an institution, because they will change the way agents of an organization accept and reproduce the norms established by the managers (Warrior \& Frezatti et al., 2006).

The introduction of an Enterprise Resource Planning system impacts operations that are carried out daily in the organizations. The ERPs are attractive because they unify the information and suggest the promise of solving integration problems, availability and issues on the reliability of information, through the incorporation of a single system that features support to various business processes in a company (Oliveira \& Ramos, 2002).

However, this is a project that for Moon (2007, p. 243), requires a significant level of resources, commitment and changes throughout the organization, which often is a major project and one that can lead a company, if not planned properly, to bankruptcy. Kumar et al. (2003) also state that these changes commit a large amount of resources, benefits and potential risks, because it is a much more complex exercise thanks to its innovation and change, than any other technology or advances.

The technical and administrative challenges, which require investments and organizational changes, provided the development of the following research question: How does legitimation occur in the implementation process of an ERP system in a holding company?

This study investigates a holding company located in the state of Santa Catarina, which is made up of companies with different activities and is having extensive difficulties in integrating management information. The reason for these difficulties arise from the use of various information systems which do not offer adequate support to provide prompt information, in addition to the rework of data entry needed, which itself leads to staff dissatisfaction and increased costs of operation and maintenance.

Several studies investigate the experiences of implementing ERPs, like Alshawi, Themistocleous and Almadani (2004); Berchet and Habchi (2005); Tchokogue et al. (2005), through the description of actual data and observations that take place in various companies.

However, studies of Le Loarne and Bécuwe (2008), in applying the typology of Suchman, to define the process of legitimation of functions within organizations, in a specific case, the implementation of a purchase module of the SAP software, concluded that deploying the software really is a typology of legitimacy.

Thus, this study is justified by highlighting the key elements pertaining to the actions that the organization surveyed opted to maintain or adjust its legitimacy. Le Loarne and Bécuwe (2008), state that after the implementation of an ERP system managers and employees from all business functions need to actually obtain, maintain or regain legitimacy, because it is not only a continuation, but an episode of an improvement process in the organization, which still needs to be validated to the point of being institutionalized. 


\section{LITERATURE REVIEW}

This section presents and discusses the theoretical aspects responsible for supporting the empirical study carried out. It is divided into New Institutional Sociology and Enterprise Resources Planning (ERP).

\subsection{New Institutional Sociology}

The institutional environment is characterized by rules, practices, beliefs, and norms to which individuals and organizations must adapt, characterized by the precepts of Institutional Theory. For Guerrero et al. (2005), the Institutional Theory presents three different approaches, the New Institutional Sociology (NIS), the New Institutional Economics (NIE) and the Old Institutional Economics (OIE), which joined, even when having different backgrounds and philosophies, share an interest in issues involving the institution and institutional change.

The New Institutional Sociology aims to verify the organizations within a network of relationships and cultural systems; so to ensure that the survival in the market, it requires adaptation of social norms, acceptable behaviors and levels of production efficiency (Covaleski \& Dirsmith, et al., 1996 ).

The institutional perspective, according to Azevedo et al. (2003), directs organizations to incorporate previously defined values and standards that initially do not bring operational efficiencies, but are considered fundamental requirements in the search for legitimacy because they enable organizations to increase their survivability.

Granlund (2001) presents issues that lead companies to the need for change in accounting systems, such as the establishment of development projects. According to the author, it is important to analyze the change of the stability and the resistance examination visible in processes of change in accounting systems, because resistance is almost always present and it is characterized as a factor that affects the success of the system.

Still, Boff (2007) stresses that, for a regulatory framework to be fully established, the imposition or adoption of a set of standards is not enough, the practice exercised and accepted by all involved in the group is also needed and that the framework becomes usual through experience.

To establish a status of legitimacy in a corporation can be a difficult task, given that a corporation is based in social perception and values that can and do change over time. To manage the legitimacy, corporations need to know how to acquire, maintain or lose, such as a change in corporate performance while social expectations for this performance remain the same (Wartick \& Mahon, 1994).

There are countless possible themes related to legitimation, which provide a list that includes an act, a rule, a procedure, a routine, a distribution, a position, a group or a team, a system of positions, a structure of the entity, an organization, organizational symbols, practices, services, programs, rules, an energy system and a system, among others (Deephouse \& Suchman, 2008).

O'Donovan (2002, p. 344), while investigating the corporate environmental disclosure, concludes that legitimation is one of the factors accounting for this disclosure. He also defines the "Legitimacy Theory is based on the idea that to continue 
operating successfully, companies must act within the limits of what a society identifies as a socially acceptable behavior."

Likewise, for Rossoni and Teixeira (2006, p. 06), legitimacy is the "social judgment of acceptance, ownership and desire that allows organizations to access other resources necessary for their survival". The premise is that legitimacy is one of the main factors that explain the survivability and resource acquisition of organizations.

A company that becomes part of a new environment has the choice of either accepting and conforming to the standards already defined and legitimized, in which case reduces the risk of rejection by other organizations and individuals, or rather establishes their own standards, manifesting itself indifferent to the standards and rules established in the environment, this way characterizing a discrepancy of behavior towards the environment in which it operates (Boff, 2007). So an entity, when it accepts to implement an integrated system according to the instructions of the supplier, performs a legitimation of an accepted procedure.

The technology by being used to automate operations, with the goal of replacing human resources, making processes faster and more efficient at a lower cost, also advances the generation of new information. Within this approach, for technological innovation to exist, there should also be social innovation, ie, provide people with knowledge so that the possibilities of an information system are maximized (Azevedo et al., 2003).

According to Boff (2007), the process of implementing a technological system makes the system already part of the company, so there is the need for legitimacy by the users for its proper use and maintenance.

\subsection{Enterprise Resource Planning - ERP}

Enterprise Resource Planning (ERP), in Moon's view (2007, p. 235), "is a company's information system designed to integrate and optimize business processes and transactions in a corporation. [...], And it is generally accepted by the industry as a practical solution for the company to achieve an integrated information system".

From the perspective of Zwicker and Souza (2000), ERPs are integrated information systems acquired in the form of commercial software packages in order to support the majority of a company's operations. However, we emphasize that to get to the complexity of companies in the present days, ERPs have gone through several development cycles, since its inception in the 1970s, until having their recognition established by major companies around the world (Alshawi \& Themistocleous et al. 2004).

However, it is possible to find these systems in small and medium enterprises, which also have resorted to implementing ERP systems in order to survive in the competitive market (Oliveira \& Ramos, 2002).

In view of Berchet and Habchi (2005), ERP systems are powerful and robust tools able to promote a real business change. Therefore, the main quality of the implementation of this system is the integration of the enterprise. Nonetheless, some problems may be encountered during the implementation process, such as: high investments of time, acquisition costs of software and peripherals, fear and rejection by users, etc. 
Operationally, an ERP system consists of a set of integrated application modules, covering most functions in an existing company. Each module covers various business processes, but all modules are completely integrated, in which all authorized users can access real-time information from various sectors of business (Scapens \& Jazayeri, 2003). The authors emphasize that integration means that data, once in the system, can be accessed throughout the enterprise, which may have consequences to it. Therefore, the implementation of an ERP system may require some changes to occur in the company, such as the way of working and the relationship between different sectors.

According to Anastas (1997), the implementation of an ERP system can raise another question as to its use : what benefits can it bring if there were a reduction in the number of employees, among other issues, since there will be an ease in obtaining information?

The process of implementing an ERP system, can be subdivided into distinct stages, so the process can be framed in stages of a life cycle. System Life Cycle, in the view of Zwicker and Souza (2000, p. 70), "represents the various stages through which a development project goes through and the use of information systems." The authors report that the life cycle idea also argues that systems pass through successive stages: growth, evolution and decline. With the closure of this cycle, other systems should be designed to better meet the needs of the company. There are several models, created by different authors, dealing with models of life cycle systems, as well as their evolution.

The life cycle model proposed by Zwicker and Souza (2000), mainly used for conducting case studies, includes three phases, namely: decision and selection, implementation and use. In the first step the company decides to implement an ERP system and selects the supplier. In the stage of implementation, the system modules are made operational by the company. Finally, in the last step the system becomes part of the day-to-day business, becoming a routine over time.

\section{METHODOLOGY}

This section presents the methodology necessary for the development of the study. It contains the characterization of the research, the method of collecting and analyzing data.

To develop the study a qualitative descriptive approach was taken through a case study. According to Richardson (1989, p. 30), the descriptive research consists of a study that "represents a level of analysis that identifies the characteristics of phenomena, allowing also the ordering and classification of these characteristics".

This study describes the case of a holding company that manages entities of diverse activities, and that it expanded its services and it needs tools that better assist managers in decision making. Given this context, the holding company is in the process of deploying an Enterprise Resources Planning (ERP) that facilitates the company's routines.

A qualitative approach was used on the research problem, which according to Beuren and Raupp (2006), is a deeper analysis in relation to the phenomenon under study and it stands out for unobserved characteristics, it is also suitable to know the nature of a social phenomenon.

In this case, as to the procedures of the research, it is characterized as a case study, in which the researcher deepens its knowledge according to a specific case. For 
Yin $(2005$, p. 20), “[...] a case study allows an investigation to retain the holistic and meaningful characteristics of real life events".

Since the research took place in only one entity, a deeper analysis is carried out and a case study will be conducted. To validate this kind of research, Yin (2005) suggests that a triangulation be structured, so validating the data collected.

For the work we used the triangulation as follows: (i) An interview with the controller of the entity, (ii) Verifying the documentation, and (iii) a questionnaire with closed questions to employees. In the interview, which took place in November 2011 with the holding company's controller, aspects were mentioned, based on previous studies (see Table 1). The analysis categories were structured so that the evidence collected in the case could be contrasted with the base literature.

\begin{tabular}{|c|c|c|c|}
\hline Analysis Category & Authors & & Question \\
\hline $\begin{array}{l}\text { To investigate how the need } \\
\text { for change occurred }\end{array}$ & $\begin{array}{l}\text { Granlund (2001); Berchet e } \\
\text { Habchi (2005); Guerreiro e } \\
\text { Pereira (2006). }\end{array}$ & 1 & $\begin{array}{l}\text { How and why did the idea } \\
\text { of implementing an ERP } \\
\text { system come to be? }\end{array}$ \\
\hline \multirow{2}{*}{$\begin{array}{l}\text { Analyze the characteristics of } \\
\text { the change process } \\
\text { implemented. }\end{array}$} & \multirow{2}{*}{$\begin{array}{l}\text { Granlund (2001); Berchet e } \\
\text { Habchi (2005); Guerreiro e } \\
\text { Pereira (2006). }\end{array}$} & 2 & $\begin{array}{l}\text { What was the process of } \\
\text { choosing the system? }\end{array}$ \\
\hline & & 3 & $\begin{array}{l}\text { What factors led to the } \\
\text { decision for the ERP } \\
\text { system? }\end{array}$ \\
\hline $\begin{array}{l}\text { Check the plan for the system } \\
\text { choice. }\end{array}$ & $\begin{array}{l}\text { Padilha e Marins (2005); } \\
\text { Oliveira e Ramos (2002); } \\
\text { Moon (2007). }\end{array}$ & 4 & $\begin{array}{l}\text { How did the planning for } \\
\text { this acquisition take place? }\end{array}$ \\
\hline $\begin{array}{l}\text { Identify the costs for ERP } \\
\text { acquisition }\end{array}$ & $\begin{array}{l}\text { Azevedo et al. (2003); Alshawi, } \\
\text { Themistocleous e Almadani } \\
\text { (2004); Le Loarne e Bécuwe } \\
(2008) .\end{array}$ & 5 & $\begin{array}{l}\text { What were the main costs } \\
\text { of this implementation? }\end{array}$ \\
\hline $\begin{array}{l}\text { Indicate the modules already } \\
\text { implemented }\end{array}$ & $\begin{array}{l}\text { Zwicker e Souza (2000); } \\
\text { Scapens e Jazayeri (2003); Le } \\
\text { Loarne e Bécuwe (2008). }\end{array}$ & 6 & $\begin{array}{l}\text { What modules have already } \\
\text { been implemented? }\end{array}$ \\
\hline $\begin{array}{l}\text { Investigate evidences about } \\
\text { the effectiveness of the } \\
\text { process }\end{array}$ & $\begin{array}{l}\text { Mahmood e Soon (1991); } \\
\text { Tchokogue et al. (2005); } \\
\text { Guerreiro e Pereira (2006). }\end{array}$ & 7 & $\begin{array}{l}\text { What is the company's } \\
\text { intention in the use of this } \\
\text { system? }\end{array}$ \\
\hline $\begin{array}{l}\text { Verify the acceptance of the } \\
\text { ERP system }\end{array}$ & $\begin{array}{l}\text { Mahmood e Soon (1991); } \\
\text { Wartick e Mahon (1994); } \\
\text { Rossoni e Teixeira (2006); } \\
\text { Moon (2007) }\end{array}$ & 8 & $\begin{array}{l}\text { What is the employee's } \\
\text { acceptance like towards the } \\
\text { ERP? }\end{array}$ \\
\hline
\end{tabular}

Table 1 - Description of categories of research analysis.

Source: Data from the study.

For documentation, we used a copy of the commercial offer from the company that provides the system that is being implemented. It contains information of the established contract with the company researched and an outsourced service provider, which oversees the implementation and support for the ERP system supplier. The information contained was about the investment, the project scope, description of services, customization, payment terms, factors relevant to the condition of the project, 
the infrastructure necessary to provide services for information technology - IT deployment and budget.

In a third step, after the interview with the controller, a questionnaire was carried out with employees who were present in the company and also involved with the implementation of this system, to compare the information with the one provided by the controller. This questionnaire was adapted from studies of Mahmood and Soon (1991), which present a Likert scale of 1 to 5 (strongly disagree to strongly agree), which aims to measure the impact after implementation of an information system, but for this study, it aimed at identifying the impact in the implementation process.

The purpose of the questionnaire is to identify the expectations of employees and the impact it has on these people who are part of the process of legitimation of the system being implemented. These people are represented by 7 individuals responsible for the financial, administrative, human resources and accounting areas. Besides these employees surveyed who work in the holding compay, the company still controls the wages of more than 50 employees located in the entities that it controls and which end up being influenced by the decision made by the management of the holding company. For these individuals the research tool wasn't applied, for they were not going through the system implementation at the time of the survey.

\section{RESULT ANALYSIS}

The entity, object of the study, operates as an asset manager, more precisely a holding company, which has operated in the market for more than 10 years, evolving over time and requiring new adaptations demanded by the market. For Oliveira (1995), a holding company is virtually any company that adopts, as its purpose, the maintenance of participation in other companies, molded not to produce physical wealth, but to control the companies producing such wealth. This basic concept has expanded to serve the interests of persons, by means of "asset protection", ie, the protection of property through the creation of a management company, subject to different rules of taxation and able to provide protections primarily on issues of succession (Hungarian, 2009).

With the responsibility of administering and controlling entities, the holding company researched is responsible for managing 15 companies from various sectors as follows; five commercial companies, a factoring, an accounting firm, to perform the internal accounts of subsidiaries, four carriers and three clothes cleaning companies, as well as managing itself.

The holding company is responsible for receiving and compiling information that will be sent to the director (the primary controller), but currently can not meet all its obligations in a timely manner, especially in relation to the receipt of the financial information of its subsidiaries, employing different mechanisms and information systems. For each business segment there was a different type of control system and, consequently, a higher maintenance cost, rework, diversified controls, among others.

After meetings with the director of the company, and from the development of a strategic plan, controllership and all the people responsible for each controlled entity decided to implement an ERP system, as it will be later witnessed in further details in the interview with the company's controller.

The interview with the controller of the company aimed to investigate how the process of implementing an ERP system in a holding company is. According to the 
interviewee, the implementation began in April of 2011 and there are still three modules that are undergoing testing and adaptation, due for completion within the next twelve months. Until December 2012, the system will be fully implemented in accordance with the specifications set by the supplier.

The controller emphasized that the idea of implementing an integrated system arose from the need for integration of information between companies and the action taken by the competition: It was not an idea, but a necessity in an increasingly turbulent world where information should be more complete, agile and faster, so that the information reaches the manager 's desk in the shortest time possible.

The controller adds that: The company has opted for an ERP to facilitate access to information to all company departments. All information would be on a consolidated basis to facilitate the administrator making some decisions and planning for the future of the company. There is no planning without having a base of information; it should be complete, well-structured and performed with confidence.

For Tchokogue et al. (2005), system integration influences the activities of business enterprises, it is a process or even in some cases a necessity, justified by dramatically improving competitiveness, considered one of the most widely used tools to optimize business re-engineering and processes.

The decision on the chosen ERP system considered several factors such as the proximity of the supplier, the knowledge of the domestic market and the relationship between the project cost and the expected benefits. Initially, we conducted a market research in order to determine the system supplier which acted with more intensity in the region near the holding company.Three major vendors were identified; all of them presented their offers.

The offer brought forward by each vendor was an important aspect in the decision, but even so, we took into consideration the supplier's national coverage capabilities, since the subsidiaries are located in several Brazilian states. Thus, the chosen supplier met all company's expectations, even having the most expensive offer, but the decision was based on the reputation and quality of services offered. The quality that this system has to offer has been proven by some tests prior to hiring the software provider, says the controller.

The factors that led the company to opt for the use of an integrated system and not simply the replacing the existing system by an equivalent, included several aspects. Firstly, as the subsidiaries are located in different states, there were flaws in the control of these companies, despite using a controllership system. There were shortcomings in the definition of cost of goods and sales prices, since some controls were performed manually with the aid of spreadsheets, all of this due to the lack of a system that met all their needs.

The controller says: We had a system that ran the company's financial side, the part of product registration; however in the area of costs and controlling there was nothing deployed, it was all in Excel. So, the chances of making mistakes in the information in a system that isn't reliable increased, since it is a simpler system that does not cover many modules, being an information searchperformed manually.

Planning for the acquisition of an ERP system included a one-year training of system users which was conducted by a specialized team appointed by the software provider. The controller reports that: With the staff we have, we would like to do the process in six months, it is a goal of ours, but over the course of the project we saw that 
there was no way to do so, because it depends a lot on people in this process, not only on systems, not only on the availability of the instructor or training and programming staff, but also on everyone from support, who must be dedicated full time to this project. The tricky part is to take a professional from his or her daily routine and to place them in such a project; this was one of the biggest challenges we had.

Besides the investment in purchasing the ERP, the company incurred expenses with network infrastructure, Internet and equipment. Initially, the centralization of all structure and implementation in the headquarters of the controlling company was tried, but when the project started, it was seen that the computer network and its peripherals did not meet the ERP needs. The controller mentions: So a new challenge has begun, we have not only invested in the system, but also on peripherasl, servers, and Internet. It was a need that added value to the company, it accelerated our process, not only a gain in the system, but in the daily lives of our employees.

Another expense that was difficult to measure was the halting of processes and employee's daily routines, four extra employees also participated, adding to the costs. There were also several weekends, holidays and trips to subsidiaries.

For a company to acquire benefits from using technology, according to Azevedo et al. (2003), the development of technological and organizational strategies is essential, so there can be an improvement in operational and strategic aspects of the organization, as it is possible to highlight the reliability of delivery, reduced time to market, optimization of information flow and quality improvement, productivity, flexibility, cost reduction, new market penetration, speed, new customers development, and new products, among others.

The implementation of the ERP through individual modules is a practice used by the supplier in order to get the client used to the new functions. The system is divided into four basic modules (market, supplies, finance and controllership). The market module is $90 \%$ solved, but there are still some adjustments that depend on other modules.

The finance module is the one that is already fully deployed, it was the first to be introduced, given its lower complexity compared to supplies and markets modules. The accounting and controllership modules have not yet been started, but it is projected to be in operation by 2012.

There are some expectations for the use and functionality of the ERP system in the company. The controller highlights that flexibility in the process is one of the main expectations. For instance, accounting has five employees doing the bookkeeping, and the new system can reduce this number to only two. However, in reducing the number of people in one sector, there are more people and more time available to give support to the company and its subsidiaries, as well as providing better management for there is relevant information for the strategic plan and for the organization as a whole. The controller says: We are offering a unique work in managerial accounting, not only in bookkeeping, like a reconciliation, for example. But we end up participating a little bit more in the company, in the management planning process and in obtaining profit to maximize the outcome of the company, cost reduction, providing more useful information to the manager.

Staff acceptance towards the ERP system, according to the controller, occurred as planned, with some resistance to the new procedures: Every change brings discontent, but I believe it is not only here, but this occurs in all businesses. However, 
there is total participation of employees, it is possible to see that everyone is very excited with the result, even though it is not an easy process.

The implementation required employees to take over more work tasks, to interact with the consulting company and to make more trips. These activities ended up disturbing the work routine. The controller said: I learned that there is no way I can follow my schedule, I have to meet the support and implementation staff, because much depends on controlling, a module that has not yet been deployed. But the rest of the team presented itself positively, better than planned.

Among the difficulties encountered in the implementation reported by the controller, there is the fulfillment of the goals established in the contract with the vendor: With the company that was hired, a time based project was started. For example, when you open the financial" module there are specific points that must be met and should be established at a certain time. As all employees were thrilled, goals were achieved in $60 \%$ of the scheduled time line. But when we entered the market module, which no longer depended on our internal structure, but depended on the subsidiaries, that was a more difficult process. We made our internal team and the supplier's team available to develop the project, but when I got to the subsidiary, it was not prepared to receive training, sometimes due to its employee turnover. During this process, we trained one person and soon after this person was repositioned or asked to leave. So, we had to do all the work again. After a few attempts, we had to restart the process, hire our own people to meet our business needs there. With that, we developed other departments in the company, able to meet all the subsidiaries needs.

To adjust the controller's responses to the answers given by the employees, Table 2 is presented and obtained with the questionnaire carried out with 7 company employees, who participate in a direct and active manner in the implementation. The scale used to answer the questionnaire was the 5-point Likert, where 1 is for strongly disagree and 5 for strongly agree.

It can be seen in the very first question that R1 confronts the others, since everyone agrees that the new system will help improve the process and the content of decisions, except for this one, which is indifferent. Probably, this respondent does not participate directly in the process of decision making in the holding company, and thus presents a view that the process still needs improvement.

In the second and third questions, respondents are unanimous in agreeing that the integrated system will improve internal discussions and meetings, as well as making coordination between functional areas of the company more effective. In the fourth question, R1 conflicts with others again, indifferent to the introduction of possible improvements to the assessment of the annual budget, while all other respondents totally agreed with that statement.

When employees were asked about increasing the profit margin of the company, fifth question, there was a discrepancy in the responses, making it clear that employees are not clear about how much, if so, the integrated system will increase the profit margin.

In the sixth question, the officials were asked about the influence of the ERP system on increasing market share, the answers vary between indifference and agree, which again suggest that employees do not have clarity about the results of the system within this specific area. The only answer that does not follow this line is R1, which 
strongly disagrees with the statement, suggesting that there is no link between the change of system and market share of the company.

\begin{tabular}{|c|c|c|c|c|c|c|c|}
\hline Questions & $\mathbf{R 1}$ & $\mathbf{R 2}$ & $\mathbf{R 3}$ & $\mathbf{R 4}$ & $\mathbf{R 5}$ & R6 & $\mathbf{R 7}$ \\
\hline $\begin{array}{l}1 \text { - Will the ERP aid in improving the process and the content of } \\
\text { the decisions? }\end{array}$ & 3 & 5 & 5 & 5 & 5 & 4 & 5 \\
\hline 2 - Will the ERP aid in the meetings and internal discussions? & 5 & 5 & 5 & 4 & 5 & 4 & 4 \\
\hline $\begin{array}{l}3 \text { - Will the ERP make it possible for a better coordination } \\
\text { among functional areas of the company? }\end{array}$ & 5 & 5 & 5 & 5 & 5 & 3 & 4 \\
\hline $\begin{array}{l}4 \text { - Will the ERP empower better evaluation of annual budget } \\
\text { reports? }\end{array}$ & 3 & 5 & 5 & 5 & 5 & 5 & 5 \\
\hline 5 - Will the ERP aid in increasing the company's profit margin? & 1 & 3 & 2 & 4 & 3 & 2 & 3 \\
\hline 6 - Will the ERP aid in increasing market share? & 1 & 4 & 3 & 4 & 4 & 3 & 3 \\
\hline 7 - Will the ERP improve strategic planning? & 5 & 4 & 5 & 5 & 5 & 4 & 2 \\
\hline $\begin{array}{l}8 \text { - Will the ERP improve communication among organizational } \\
\text { units from different regions? }\end{array}$ & 5 & 5 & 4 & 5 & 5 & 5 & 4 \\
\hline $\begin{array}{l}9 \text { - Will the ERP aid in coordinating regional, domestic and } \\
\text { worldwide activities? }\end{array}$ & 5 & 5 & 4 & 5 & 5 & 4 & 4 \\
\hline $\begin{array}{l}10 \text { - Will the ERP aid in closely controlling its clients and } \\
\text { suppliers? }\end{array}$ & 3 & 5 & 5 & 5 & 5 & 5 & 3 \\
\hline $\begin{array}{l}11 \text { - Will the ERP make it possible for the company to add more } \\
\text { information to the services? }\end{array}$ & 3 & 5 & 5 & 5 & 5 & 2 & 5 \\
\hline
\end{tabular}

Table 2 - Responses to the questionnaire

Source: Survey data.

When questioned about the improvement of the company's strategic plan, the respondents almost unanimously agree with the statement. But this time respondent 6 is confronted, maybe not distinguishing the link between strategic planning and implementation of the integrated system.

In the eighth question, and in the ninth, the majority of respondents agree or strongly agree with the statements made. In this context, it can be said that most employees agree that the use of the ERP system will improve the communication pattern of the company and also help coordinate the company's activities at the national, state or municipal level.

When asked about the connection between the control of customers and suppliers and the use of an integrated system, the majority of respondents are unanimous in completely agreeing, however R1 and R7 are indifferent to the statement.

Finally, question number 11 sought to investigate whether staff agreed that the implementation of the ERP system would add more information to the services it provides, in this sense most respondents said they totally agree, while only respondent $\mathrm{R} 1$ is indifferent and R6 disagrees. 


\section{FINAL CONSIDERATIONS}

The research aimed to evaluate the legitimation in the process of implementing an ERP system in a holding company. We conducted a case study on a asset management company, which manages 15 companies from various sectors as follows; five commercial companies, a factoring, an accounting firm, to perform the internal accounts of subsidiaries, four carriers and three clothes cleaning companies. The triangulation of data was performed by analysis of documents, interviews with the company's controller and a questionnaire to employees.

The results show that the need for a change of system to an ERP came from the market, in the analysis of its competitors, for the company should either update itself or it would no longer be able to compete, said the controller. This argument is consistent with Azevedo et al. (2003), in which it is mentioned that companies undergo major changes and restructuring, due to consumer demand, a greater number of competitors in the market and a workforce that requires new types of treatments.

The ERP system can generate various benefits, such as operational, financial, investors, and user satisfaction, among others. Due to its relevance, its importance can be measured by observing the reactions of the market, as well as the announcement of use, according to Moon (2007).

The choice of an ERP system obeyed criteria from an analysis of expected costs and benefits. The controller said that the lowest quotation presented would not necessarily be the chosen on. In the case of the company studied the highest quotation was chosen because the offer presented other benefits deemed important like the quality of service provided by the company support and assistance in the process of ERP implementation.

The stage in which the system is chosen is decisive, present Berchet and Habchi (2005). The company will set, along with the software vendor, all procedures and resources required for the acquisition and operation of the integrated system, and a bad choice can cause problems in the future.

The company chose to implement a system that would guarantee information security, so, the decision was made for an integrated system which modified and improved company management, since the company was using a specific information system for each sector, with the exception of the controllership and costs departments, which were sharing spreadsheets. According to Le Loarne and Bécuwe (2008), the reason for a company to implement an ERP system is usually cost reduction. In order for the procedure to be performed, the system must be established and run by an assigned project team and assisted by external consultants, redesigning the business process, establishing the procedures for every module and defining the parameters.

Moon (2007) clarifies that identifying the amount that will be spent on the new system is often decisive and a key issue for the choice of a supplier, so that spending can be known beforehand. Moon (2007) also shows the importance of a good project and the participation of all stakeholders in the organization. Zwicker and Souza (2000) show that the planning phase is important because it takes into account criteria that can help managers choose the most appropriate integrated system for the reality of each company. 
The controller notes that the company's investment to implement the ERP system was high because it was more than just the amount for the integrated system itself; it was necessary to invest in new equipment and staff training.

The arguments presented by the controller in response to the subject, collaborate with the precepts of institutionalization, which for Covaleski, Dirsmith and Samuel (1996) is an adaptive process that takes into account certain rules in effect and that influence organizations on their beliefs, norms and traditions.

The implementation of a full ERP system, according to Le Loarne and Bécuwe (2008), involves the deployment of multiple modules, each module being related to a specific function of the organization, such as accounting, finance, procurement, human resources, production, etc. In this sense, considering that two controlling modules have been fully implemented, and two, accounting and controllership, not yet. These two modules will have the implementation started in early 2012 due to the company's specific needs.

Among the expectations with the ERP system, the company expected and still expects faster processes, the reduction of rework and release of employees, information for the management of companies and result planning. These expectations serve those described in the study by Anastas (1997), especially regarding expectations with respect to reducing the number of employees performing a particular function and so that they can start contributing to the retrieval of management information.

The collected data show that there was staff involvement, ready to solve problems and willing to attend training. Nevertheless, the controller noted that such a big change causes some situations of discomfort, but through team cooperation the conflicts can be minimized.

The analysis of the questionnaire shows the impact of legitimacy by the employees, being in general satisfied with the implementation process and also having high expectations of changes and the impacts on the company. The documents analyzed completed the information obtained in the interview, especially with respect to costs, benefits, hours devoted to training and troubleshooting.

Azevedo et al. (2003), argue that the institutional perspective directs companies to making the incorporation of values and predefined patterns, which initially do not bring operational efficiency, they are however considered fundamental requirements in the search for legitimacy, increasing the company's survivability.

Boff (2007) also emphasizes that for a normative structure to be fully established, the imposition or adoption of a set of standards is not enough, but it is necessary that it be practiced and accepted by everyone in the group, until it becomes usual for everyone involved in the company. This is because it is not enough to deploy a system without the acceptance of all employees, because it may cause other internal conflicts and discouragement of the team and something that was made to help problem solving may cause even more complications.

In this context, the contribution of this study is showing the experiences of the company's situation. The company goes through this process of change in legitimizing the new information system, because the company controls various activities of difficult reconciliation and comparison and it requires specific controls and precision. An acceptance and understanding by employees and management can be identified. 
It is suggested, for future research, the study of the company after finalizing the full implementation of the ERP system, as well as the study of other companies that have already made changes in their management controls.

\section{REFERENCES}

Alshawi, S.; Themistocleous, M.; Almadani, R. (2004). Integrating diverse ERP systems: a case study. Journal of Enterprise Information Management. 17 (6): 454-462.

Anastas, M. (1997). The changing world of management accounting and financial management. Management Accounting, p. 48-51.

Azevedo, C. G. D.; Machado, A. G. C.; Frota, I. L. N.; Zenaide; M. L. C.; Barbosa Júnior, C. L. (2003). Implantação de um sistema ERP: a mudança organizacional sob os aspectos contingencial e institucional. Anais do ENANPAD. Atibaia, Rio de Janeiro, Brasil, 27.

Berchet, C.; Habchi, G. (2005). The implementation and deployment of an ERP system: an industrial case study, Computers in Industry, 56: 588-605.

Boff, M. L. (2007). Estratégias de legitimidade organizacional de Lindblom na evidenciação ambiental e social em relatórios da administração de empresas familiares. 2007. 160 f. Dissertação de Mestrado em Ciências Contábeis - Programa de Pós-Graduação em Ciências Contábeis da Universidade Regional de Blumenau, Blumenau.

Covaleski, M. A.; Dirsmith, M. W.; Samuel, S. (1996). Managerial accounting research: the contributions of organizational and sociological theories. Journal of Management Accounting Research, 8: 1-35.

Deephouse, D. L.; Suchman, M. In: Greenwood, R.; Oliver, C.; Suddaby, R.; SahlinAndersson, K. (2008). The sage handbook of organizational institutionalism. London: Sage publications, p. 49-77.

Granlund, M. (2001). Towards explaining stability in and around management accounting systems. Management Accounting Research, 12: 141-166.

Guerreiro, R.; Frezatti, F.; Casado, T. (2006). Em busca de um melhor entendimento da contabilidade gerencial através da integração de conceitos da psicologia, cultura organizacional e teoria institucional. Revista de Contabilidade Finanças, 17: 7-21.

Guerreiro, R.; Frezatti, F.; Lopes, A. B.; Pereira, C. A. (2005). O entendimento da contabilidade gerencial sob a ótica da teoria institucional. Revista Organizações \& Sociedade, 12 (35): 91-106.

Guerreiro, R.; Pereira, C. A. (2006). Aplicação do modelo de Burns e Scapens para avaliação do processo de institucionalização da contabilidade gerencial. Anais do Encontro da Associação Nacional de Pós Graduação e Pesquisa em Administração, Salvador, Bahia, Brasil, 30. 
Hungaro, F. M. (2009). A figura das empresas holding como forma de proteção patrimonial, planejamento sucessório e controle de grupos empresariais. Revista ETIC Encontro de Iniciação Científica, 5 (5): 1-16.

Kumar, V., Maheshwari, B., Kumar, U. (2003). An investigation of critical management issues in ERP implementation: empirical evidence from Canadian organizations, Technovation, 23 (10):793-807.

Le Loarne, S. Bécuwe, A. (2008). Exploring functional legitimacy within organisations: lessons to be learnt from suchman's typology. The case of the purchasing function and SAP Implementation, p. 101-118. In: GRABOT, B.; MAYÈRE, A.; BAZET, I. ERP systems and organisational change: a socio-technical insight. Springer, p. 101- 110. Disponível em <http://www.springerlink.com/content/978-1-84800-1824/\#section=207643\&page=2\&locus=6> . Acesso em: 24 jan. 2012.

Mahmood, M. A.;Soon, K. S. A comprehensive model for measuring the potential impact of information technology on organizational strategic variables. Decision Sciences; Sep/Oct 1991; 22, 4; ABI/INFORM Complete, p. 869-897.

Moon, Y. B. (2007). Enterprise Resource Planning (ERP): a review of the literature. Int. J. Management and Enterprise Development, 4 (3): 235-264.

O'donovan, G. (2002). Environmental disclosures in the annual report: Extending tha applicability and predictive power of legitimacy theory. Accounting, Auditing \& Accountability Journal, 15 (3): 344-371.

Oliveira, D. P. R. (1995). Holding, administração corporativa e unidade estratégica de negócio: uma abordagem pratica. São Paulo: Atlas.

Oliveira, M. A.; Ramos, A. S. M. (2002). Fatores de sucesso na implementação de sistemas integrados de gestão empresarial (ERP): estudo de caso em uma média empresa. Anais do Encontro Nacional de Engenharia de Produção, Curitiba, Paraná, Brasil, 22.

Padilha, T. C. C.; Marins, F. A. S. (2005). Sistemas ERP: características, custos e tendências. Revista Produção, 15 (01): 102-113.

Raupp, F. M; Beuren, I. M. In: Beuren, I. M.; Longaray, A. A. (2006). Como elaborar trabalhos monográficos em contabilidade: teoria e prática. (3. ed.). atual. São Paulo: Atlas.

Richardson, R. J.; Peres, J. A. S. (1989). Pesquisa social: métodos e técnicas. (2. ed.) São Paulo: Atlas, p. 286.

Rossoni, L.; Machado-Da-Silva, C. L. (2010). Legitimidade, governança corporativa e desempenho: análise das empresas da bolsa de valores de São Paulo. Anais do Enanpad, Rio de Janeiro, Rio de Janeiro, Brasil, 34.

Scapens, R. W.; Jazayeri, M. (2003). ERP systems and management accounting change: opportunities or impacts? A resserach note. European Accountig Review, 12 (1): 201233.

Tchokogue, A., Bareil, C., et al. (2005). Key lessons from the implementation of an ERP at Pratt \& Whitney Canada. International Journal of Production Economics, 95 (2): 151-163.

Yin, R. K. (2005). Estudo de caso: planejamento e métodos. (3 . Ed.). Porto Alegre, RS: Bookman, p. 212. 
302 Theiss, V., Krespi, N. T., Lavarda, C. E. F.

Zwicker, R.; Souza, C. A. (2006). Sistemas ERP: conceituação, ciclo de vida e estudos de casos comparados. In: Souza, C. A. de; Saccol, A. Z. Sistemas ERP no Brasil (Enterpirse Resource Planning): teoria e casos. São Paulo: Atlas.

Wartick, S. L. Mahon, J. F. (1994). Toward a substantive definition of the corporate issue construct: a review and synthesis of the literature. Business and Society, 33: 293311. 